\title{
Association of rs9939609-FTO with metabolic syndrome components among women from Mayan communities of Chiapas, Mexico
}

\author{
Pilar E. Núñez Ortega ${ }^{1}$, María E. Meneses², Iván Delgado-Enciso ${ }^{3,4}$, César Antonio Irecta-Nájera, \\ Itandehui Castro-Quezada', Roberto Solís-Hernández', Elena Flores-Guillén ${ }^{6}$, Rosario García-Miranda,7, \\ Adán Valladares-Salgado ${ }^{8}$, Daniel Locia-Morales ${ }^{8}$ and Héctor Ochoa-Díaz-López ${ }^{* *}$
}

\begin{abstract}
Background: Metabolic syndrome (MetS) is a complex cluster of risk factors, considered as a polygenic and multifactorial entity. The objective of this study was to determine the association of rs9939609-FTO polymorphism and MetS components in adult women of Mayan communities of Chiapas.

Methods: In a cross-sectional study, sociodemographic, anthropometric, clinical, and biochemical data were obtained from 291 adult women from three regions of Chiapas, Mexico. The prevalence of MetS and the allele and genotype frequencies of the rs9939609-FTO were estimated. Multivariate logistic regression models were used to assess the association of the single nucleotide polymorphism (SNP) with each of the MetS components.
\end{abstract}

Results: The MetS prevalence was 60\%. We found a statistically significant association between rs9939609-FTO and hyperglycemia in the dominant model (OR 2.6; $95 \%$ Cl 1.3-5.3; $p=0.007$ ).

Conclusions: Women from Mayan communities of Chiapas presented a high prevalence of MetS and a relevant association of the FTO variant with hyperglycemia. This is the first study carried out in these Mayan indigenous communities from Chiapas.

Keywords: Metabolic syndrome, Single nucleotide polymorphisms, FTO, Mayan indigenous women, Chiapas, Mexico

\section{Background}

Chronic diseases are one of the biggest challenges that Mexico's health system is facing [1]. This is due to their high prevalence, great contribution to overall mortality, premature disability, and high costs of their treatment. Metabolic syndrome (MetS) is characterized by the presence of insulin resistance, hyperglycemia and/

*Correspondence: hochoa@ecosur.mx

${ }^{1}$ Health Department, El Colegio de La Frontera Sur, San Cristóbal de Las Casas, Chiapas, Mexico

Full list of author information is available at the end of the article or type 2 diabetes (T2D), dyslipidemias, abdominal obesity, high blood pressure (HBP), and endothelial dysfunction [2]. All these alterations may sequentially or simultaneously be present in MetS, potentially contribute to the development of cardiovascular diseases (CVD) [3], and confer a high risk of morbidity/mortality [4].

Due to the complexity of this set of pathologies, comprehensive studies are currently carried out for a better understanding of its pathophysiology. MetS has been considered a polygenic and multifactorial entity [5]. Family and population studies show that MetS is original author(s) and the source, provide a link to the Creative Commons licence, and indicate if changes were made. The images or other third party material in this article are included in the article's Creative Commons licence, unless indicated otherwise in a credit line to the material. If material is not included in the article's Creative Commons licence and your intended use is not permitted by statutory regulation or exceeds the permitted use, you will need to obtain permission directly from the copyright holder. To view a copy of this licence, visit http://creativecommons.org/licenses/by/4.0/. The Creative Commons Public Domain Dedication waiver (http://creativeco mmons.org/publicdomain/zero/1.0/) applies to the data made available in this article, unless otherwise stated in a credit line to the data. 
influenced by a strong genetic component, with great variability among different ethnic groups. In fact, $45 \%$ of first-grade family members of patients with T2D, even at normal glucose levels, show to have insulin resistance [6].

In our study, we evaluated the single nucleotide polymorphism (SNP), rs9939609, located at the first intron of the FTO gene. This SNP is one of the most extensively studied, explaining approximately $1 \%$ of body mass index (BMI) heritability [7]. In addition, several studies have systematically confirmed the association of a group of SNPs in the first intron of this gene with obesity-related traits in Europeans [7-9], Asian [10, $11]$, and African populations [12, 13].

With regard to the Mexican mestizo population, there are studies that have shown the association of this genetic variant with the development of the pathologies involved in MetS [14, 15]. Although the function of the FTO protein has not been clearly elucidated, some previous studies linked this protein to impaired fasting glucose and insulin resistance [1618]. However, the association of this FTO variant has not been studied in Mayan indigenous communities from Chiapas, Mexico.

The objective of this research was to determine the prevalence of MetS and the allele frequency of the SNP rs9939609-FTO as well as its association with the components of Mets in women from Mayan indigenous communities of Chiapas, Mexico.

\section{Methods}

\section{Study population}

The study population belongs to three regions of Mayan ancestry of Chiapas, Mexico: Tzotzil-Tzeltal (11 communities), Selva (79 communities), and Soconusco ( 2 communities). Data were collected from two cross-sectional studies conducted in 2017-2018 in the regions mentioned above $[19,20]$. In total, 310 women participated in these studies. A high percentage of the general population of these regions belongs to marginalized and extremely poor indigenous groups (Fig. 1). Participants with missing information in the main variables of this study were excluded $(n=12)$ from the analysis. The final sample included 291 individuals. All participants gave their informed consent for inclusion in the study.

\section{Data collection}

A validated structured questionnaire was applied with the following sections: sociodemographic data, nonpathological personal history, family medical history, anthropometric and clinical measures, and frequency of food consumption. Sociodemographic data included age, geographic area, ethnicity and years of schooling, household items, and type of cooking fuel.

Family medical history included first and second degree of consanguinity relatives' diseases: obesity, diabetes, HBP, and CVD. Non-pathological personal history included smoking and alcohol consumption.
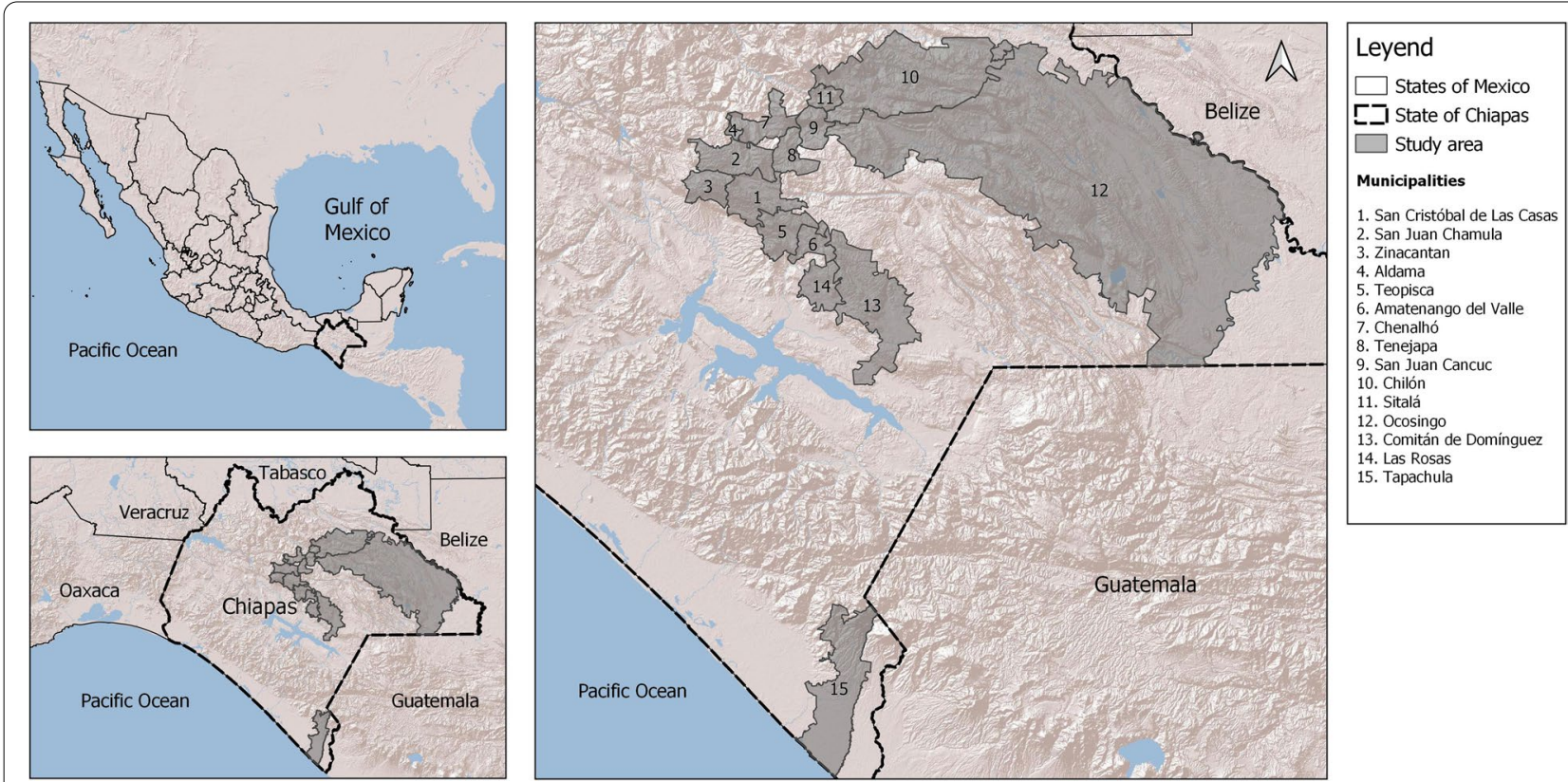

Fig. 1 Study area:Tzotzil-Tzeltal, Selva, and Soconusco regions of Chiapas, Mexico 


\section{Anthropometric and clinical assessment}

Weight $(\mathrm{kg})$ was measured by electronic scales (Model UM081, Tanita Corporation, accuracy \pm 100 g, Tokyo, Japan). Height $(m)$ was measured using stadiometers (SECA, accuracy $\pm 1 \mathrm{~mm}$, Berlin, Germany). Waist circumference was measured by anthropometric tapes (SECA, precision $\pm 1 \mathrm{~mm}$, Berlin, Germany). BMI was estimated as weight divided by height squared. Then, weight status was categorized as follows: underweight and normal weight $\left(\mathrm{BMI}<25 \mathrm{~kg} / \mathrm{m}^{2}\right)$ and overweight or obesity $\left(\mathrm{BMI} \geq 25 \mathrm{~kg} / \mathrm{m}^{2}\right)$.

Blood pressure was measured twice, using a digital monitor (Model CH-453, Citizen, Japan). The readings were taken with the participant seated and after a 5-min rest.

\section{Frequency of food consumption}

The frequency of food intake was assessed by using a 37-item food frequency questionnaire (FFQ) [19]. Participants were asked on how often they consumed each food over 1 week. The frequency of food intake was categorized as follows: $0-1,2-4$, or 5 or more times per week.

\section{Biochemical measurements}

Fasting 5-mL blood samples $(10 \mathrm{~h})$ were taken from the antecubital vein for biochemical analysis. The determinations of serum glucose, triglycerides, and HDL-c were performed by photometric enzymatic methods (Diasys, Diagnostic System, Holzheim, Germany), in an automated analyzer (Vitalab Selectra E, Vitalab Scientific, Îlede-France, France).

\section{Classification of metabolic syndrome (MetS)}

MetS was identified using the criteria of the Joint Statement of International Diabetes Federation Task Force on Epidemiology and Prevention; National Heart, Lung, and Blood Institute; American Heart Association; World Heart Federation; International Atherosclerosis Society; and International Association for the Study of Obesity [21]. MetS was defined as the presence of three or more of the following conditions: elevated waist circumference $(\geq 80 \mathrm{~cm})$; elevated triglycerides $(\geq 150 \mathrm{mg} / \mathrm{dL})$ or drug treatment for elevated triglycerides; reduced HDL-c $<50 \mathrm{mg} / \mathrm{dL}$ or drug treatment for reduced HDLc; systolic blood pressure (SBP) $\geq 130 \mathrm{~mm} \mathrm{Hg}$ or diastolic blood pressure $(\mathrm{DBP}) \geq 85 \mathrm{mmHg}$ or antihypertensive drug treatment in a patient with a history of hypertension; and fasting glucose levels $\geq 100 \mathrm{mg} / \mathrm{dL}$ or drug treatment for elevated glucose.

\section{Genotyping}

The isolation of genomic DNA was performed in ECOSUR Health Laboratory at San Cristobal de Las Casas,
Chiapas, using commercial kits based on columns (Universal Quick-DNATM Kit/Zymo Research, USA). The DNA samples were frozen at $-42{ }^{\circ} \mathrm{C}$ and transported to the Biochemistry Unit of the Centro Médico Nacional Siglo XXI (National Medical Center of the 21st Century) in Mexico City, where all the molecular analyses were performed. The purity and concentration of genomic DNA were verified by spectrophotometry at $260 / 280 \mathrm{~nm}$ (Epoch, Biotek, Winooski, Vermont), and the integrity of the DNA was confirmed by electrophoresis in an agarose gel at $0.8 \%$. The analysis of the SNP rs9939609-FTO was made using TaqMan-probe-based real-time PCR (7900HT Applied Biosystems, Foster City, CA, USA), following standard protocols. A concordance of $100 \%$ was observed in 30 duplicate samples for quality control of each probe.

\section{Statistical analysis}

A descriptive analysis of the variables was performed by MetS using percentages and 95\% confidence intervals $(95 \% \mathrm{CI})$ for categorical variables. For continuous variables, we have conducted the Shapiro-Wilk test for normal data distribution. Medians and interquartile ranges were calculated for skewed biochemical and dietary measurements. Differences between groups were analyzed using chi-square tests for categorical variables and Mann- Whitney $U$ tests for continuous variables. Allele and genotype frequencies were estimated. Hardy-Weinberg equilibrium (HWE) was estimated for the variant under study. To assess the association between MetS components and rs9939609-FTO, logistic regression models assuming three different modes of inheritance (codominant, dominant, and recessive) were fitted. Odds ratios (ORs) and 95\% CI were estimated to measure the magnitude of association between rs9939609-FTO and MetS components. Models were adjusted for age (years, continuous), BMI ( $\mathrm{kg} / \mathrm{m}^{2}$, continuous), schooling (years, continuous), and presence of T2D. For all the analyses, we considered a $p$-value of $\leq 0.05$ as a significant level. To assess a possible interaction between geographic region or previously diagnosed hypertension and rs9939609-FTO, we introduced the product terms of the variables in the logistic regression models and considered $p<0.05$ in the likelihood ratio test as statistically significant. All analyses were performed using STATA software (StataCorp, College Station, TX 77,845, USA; version 16.1, 2019).

\section{Results}

Sociodemographic characteristics of the study population by MetS

The sociodemographic characteristics of the study population by MetS are shown in Table 1 . Women over 45 years had the highest prevalence of MetS (75\%). 
Women living in rural areas had a higher prevalence of MetS than those living in urban areas (localities of more than 2500 people) which in Mexico represents more than $70 \%$ of its geographical area.

Women with less than 5 years of schooling had a higher prevalence of MetS than those with the highest schooling. Women who speak an indigenous language had a slightly higher prevalence of MetS (62\%) than women who only speak Spanish (60\%). With regard to household conditions, a great proportion of the study population lacks basic amenities such as piped water inside the house, stove, and fridge. However, no marked differences were observed.

\section{Anthropometric, clinical, and biochemical parameters of the study population by MetS}

Table 2 shows the anthropometric, clinical, and biochemical parameters of the study population by MetS. Ninety-two percent of the total participants had a waist circumference greater than $80 \mathrm{~cm}$. A high percentage of them (88\%) presented a $\mathrm{BMI} \geq 25 \mathrm{~kg} / \mathrm{m}^{2}, 61 \%$ had high level of triglycerides $(\geq 150 \mathrm{mg} / \mathrm{dL})$, and $70 \%$ had low HDL-c $(<50 \mathrm{mg} / \mathrm{dL})$. We identified a low percentage of women with alterations in fasting glucose and blood pressure levels (22\% and 32\%, respectively).

Among women with MetS, 99\% had a waist circumference greater than $80 \mathrm{~cm}, 96 \%$ presented overweight or obesity, $87 \%$ had high levels of triglycerides, and $85 \%$ had low HDL-c levels. Thirty-three percent presented hyperglycemia and $49 \%$ HBP.

\section{Comorbidities and frequency of food consumption according to MetS}

Women with MetS had a higher prevalence of T2D, hypertension, and polycystic ovary syndrome than women without MetS (Table 3). They consumed the following food groups five or more times per week: dairy products $(41 \%)$, fruits $(40 \%)$, vegetables $(37 \%)$, red meat (3.5\%), poultry $(1.7 \%)$, cereals and tubers $(100 \%)$, legumes $(75 \%)$, and sugar-sweetened beverages (13.3\%). No statistically significant differences between food groups were observed between women with and without MetS.

\section{Allele and genotype frequencies of the study population}

Table 4 shows the allele frequencies of the rs9939609FTO analyzed in our study population and their comparison with those reported in other studies for main blocks of the population (American, European, East Asian, African) and Mexican population. In our study, the SNP rs9939609 was in HWE $(p>0.05)$. TT genotype was identified in 233 samples (80\%), TA in 54 samples
(18\%), and AA in 4 samples (1\%). The frequency of the A allele was 0.10 .

There are statistically significant differences between the frequencies reported in our study and those reported for American, European, African, and Mexican populations. No significant differences were found between the allele frequency reported for the East Asian population and our study population.

\section{Association between MetS components and different rs9939609-FTO genotypes in the study population}

We analyzed different modes of inheritance (co-dominant, dominant, and recessive) for the rs9939609-FTO genotypes with regard to MetS components. Table 5 shows the association between rs9939609-FTO and hyperglycemia in the study population. For this analysis, only individuals who presented fasting glucose levels $\geq 100 \mathrm{mg} / \mathrm{dL}$ were considered (treatment for elevated glucose was not included as an outcome). A significant association was observed between the rs9939609/ FTO and hyperglycemia in the dominant model. The TA/AA genotype carriers were twice more likely to develop hyperglycemia than those with the TT genotype (OR $=2.6$; 95\% CI 1.3-5.3, $p=0.007$ ).

No significant interactions were observed for the geographic region or previously diagnosed hypertension ( $p$ for interaction $>0.05$ ).

\section{Discussion}

MetS has been associated with an increased risk of developing CVD and T2D [21]. In Mexico, some studies have been conducted to estimate the proportion of the Mexican population with MetS. For instance, Aguilar-Salinas et al. [24] reported in 2004 a prevalence of $14 \%$ according to the World Health Organization (WHO) criteria and $27 \%$ according to the National Cholesterol Education Program Adult Treatment Panel III (NCEP-ATPIII) criteria in population from 20 to 69 years of age. González-Villalpando et al. [14] in a study performed among the Mexican diabetic population reported MetS prevalence of $39.9 \%$ and $59.9 \%$ in males and females, respectively, based on the NCEPATPIII criteria. It is noteworthy that previous studies were carried out in other Mexican states such as Guanajuato, Jalisco, Puebla, Baja California Norte, Morelos, Querétaro, and Mexico City [25]. By contrast, in the southeast region of the country with a high proportion of the indigenous population, only few studies have been carried out on this topic. As an example, the study conducted by Castro et al. in 2011 identified a prevalence of $49 \%$ of MetS in adults from Merida, Yucatan, according to the IDF criteria [26]. We found that $60 \%$ of 
Table 1 Sociodemographic characteristics of the study population by MetS

\begin{tabular}{|c|c|c|c|c|c|c|c|c|c|c|c|}
\hline & \multicolumn{4}{|c|}{ Without MetS } & \multicolumn{4}{|c|}{ With MetS } & \multicolumn{2}{|c|}{ Total } & \multirow[t]{2}{*}{$P$-value* } \\
\hline & $n$ & $\%$ or median & \multicolumn{2}{|c|}{$\begin{array}{l}\text { 95\% Cl or p25- } \\
\text { p75 }\end{array}$} & $n$ & $\%$ or median & \multicolumn{2}{|c|}{$95 \% \mathrm{Cl}$ or p25-p75 } & $n$ & & \\
\hline \multicolumn{12}{|l|}{ Characteristics } \\
\hline \multicolumn{12}{|l|}{ Age } \\
\hline Years & 116 & 37.0 & 33.0 & 43.0 & 175 & 40.0 & 35.0 & 47.0 & 291 & 100 & $0.001+$ \\
\hline$<35$ years & 39 & 53.4 & 42.0 & 64.5 & 34 & 46.6 & 35.5 & 58.0 & 73 & 100 & 0.006 \\
\hline $35-40$ years & 35 & 38.9 & 29.3 & 49.2 & 55 & 61.1 & 50.8 & 70.7 & 90 & 100 & \\
\hline $41-45$ years & 24 & 42.9 & 30.5 & 55.9 & 32 & 57.1 & 44.1 & 69.5 & 56 & 100 & \\
\hline$>45$ years & 18 & 25.0 & 16.1 & 35.8 & 54 & 75.0 & 64.2 & 83.9 & 72 & 100 & \\
\hline Total & 116 & 39.9 & 34.4 & 45.6 & 175 & 60.1 & 54.4 & 65.6 & 291 & 100 & \\
\hline \multicolumn{12}{|l|}{ Geographic area } \\
\hline Urban & 94 & 40.7 & 34.5 & 47.1 & 137 & 59.3 & 52.9 & 65.5 & 231 & 100 & 0.570 \\
\hline Rural & 22 & 36.7 & 25.3 & 49.3 & 38 & 63.3 & 50.7 & 74.7 & 60 & 100 & \\
\hline Total & 116 & 39.9 & 34.4 & 45.6 & 175 & 60.1 & 54.4 & 65.6 & 291 & 100 & \\
\hline \multicolumn{12}{|l|}{ Years of schooling } \\
\hline Years & 116 & 9.0 & 4.3 & 12.0 & 175 & 6.0 & 2.0 & 9.0 & 291 & 100 & $<0.001 \dagger$ \\
\hline $0-5$ years & 34 & 32.1 & 23.8 & 41.4 & 72 & 67.9 & 58.6 & 76.2 & 106 & 100 & 0.008 \\
\hline $6-10$ years & 52 & 39.1 & 31.1 & 47.6 & 81 & 60.9 & 52.4 & 68.9 & 133 & 100 & \\
\hline$>10$ years & 30 & 57.7 & 44.2 & 70.4 & 22 & 42.3 & 29.6 & 55.8 & 52 & 100 & \\
\hline Total & 116 & 39.9 & 34.4 & 45.6 & 175 & 60.1 & 54.4 & 65.6 & 291 & 100 & \\
\hline \multicolumn{12}{|c|}{ Language (ethnicity) } \\
\hline Spanish & 76 & 41.1 & 34.2 & 48.3 & 109 & 58.9 & 51.7 & 65.8 & 185 & 100 & 0.575 \\
\hline $\begin{array}{l}\text { Indigenous (any } \\
\text { Mayan languages) }\end{array}$ & 40 & 37.7 & 28.9 & 47.2 & 66 & 62.3 & 52.8 & 71.1 & 106 & 100 & \\
\hline Total & 116 & 39.9 & 34.4 & 45.6 & 175 & 60.1 & 54.40 & 65.6 & 291 & 100 & \\
\hline \multicolumn{12}{|l|}{ Household conditions } \\
\hline \multicolumn{12}{|c|}{ Piped water within the house } \\
\hline Yes & 98 & 42.2 & 36.0 & 48.7 & 134 & 57.8 & 51.3 & 64.0 & 232 & 100 & 0.100 \\
\hline No & 18 & 30.5 & 19.9 & 43.0 & 41 & 69.5 & 57.0 & 80.1 & 59 & 100 & \\
\hline Total & 116 & 39.9 & 34.4 & 45.6 & 175 & 60.1 & 54.4 & 65.6 & 291 & 100 & \\
\hline \multicolumn{12}{|l|}{ Cooking fuel } \\
\hline Wood or coal & 39 & 47.0 & 36.5 & 57.7 & 44 & 53.0 & 42.3 & 63.5 & 83 & 100 & 0.272 \\
\hline Gas or electric & 32 & 35.6 & 26.2 & 45.8 & 58 & 64.4 & 54.2 & 73.8 & 90 & 100 & \\
\hline Both & 45 & 38.1 & 29.7 & 47.1 & 73 & 61.9 & 52.9 & 70.3 & 118 & 100 & \\
\hline Total & 116 & 39.9 & 34.4 & 45.6 & 175 & 60.1 & 54.4 & 65.6 & 291 & 100 & \\
\hline \multicolumn{12}{|l|}{ Television } \\
\hline No & 12 & 37.5 & 22.4 & 54.8 & 20 & 62.5 & 45.2 & 77.6 & 32 & 100 & 0.772 \\
\hline Yes & 104 & 40.2 & 34.3 & 46.2 & 155 & 59.8 & 53.8 & 65.7 & 259 & 100 & \\
\hline Total & 116 & 39.9 & 34.4 & 45.6 & 175 & 60.1 & 54.4 & 65.6 & 291 & 100 & \\
\hline \multicolumn{12}{|l|}{ Microwave oven } \\
\hline No & 83 & 39.5 & 33.1 & 46.2 & 127 & 60.5 & 53.8 & 66.9 & 210 & 100 & 0.849 \\
\hline Yes & 33 & 40.7 & 30.5 & 51.6 & 48 & 59.3 & 48.4 & 69.5 & 81 & 100 & \\
\hline Total & 116 & 39.9 & 34.4 & 45.6 & 175 & 60.1 & 54.4 & 65.6 & 291 & 100 & \\
\hline \multicolumn{12}{|c|}{ Cell phone (head of the household) } \\
\hline No & 32 & 42.7 & 31.9 & 54.0 & 43 & 57.3 & 46.0 & 68.1 & 75 & 100 & 0.565 \\
\hline Yes & 84 & 38.9 & 32.6 & 45.5 & 132 & 61.1 & 54.5 & 67.4 & 216 & 100 & \\
\hline Total & 116 & 39.9 & 34.4 & 45.6 & 175 & 60.1 & 54.4 & 65.6 & 291 & 100 & \\
\hline \multicolumn{12}{|l|}{ Fridge } \\
\hline No & 32 & 38.1 & 28.3 & 48.7 & 52 & 61.9 & 51.3 & 71.7 & 84 & 100 & 0.695 \\
\hline Yes & 84 & 40.6 & 34.1 & 47.4 & 123 & 59.4 & 52.6 & 65.9 & 207 & 100 & \\
\hline Total & 116 & 39.9 & 34.4 & 45.6 & 175 & 60.1 & 54.4 & 65.6 & 291 & 100 & \\
\hline
\end{tabular}

${ }^{*}$ Chi-square test for independence. Mann-Whitney $U$ test 
Table 2 Anthropometric, clinical, and biochemical parameters of the study population by MetS

\begin{tabular}{|c|c|c|c|c|c|c|}
\hline Variables & With MetS (n) & $\begin{array}{l}\text { Median (p25-p75) } \\
\text { or } \%(95 \% \mathrm{Cl})\end{array}$ & $\begin{array}{l}\text { Without } \\
\text { MetS }(n)\end{array}$ & $\begin{array}{l}\text { Median (p25-p75) } \\
\text { or } \%(95 \% \mathrm{Cl})\end{array}$ & Total & Median or $\%(95 \% \mathrm{Cl})$ \\
\hline Waist circumference & 175 & $95(88-102)$ & 116 & $90(84-84.5)$ & 291 & $93(92-95)$ \\
\hline$<80 \mathrm{~cm}$ & 2 & $1.1\left(^{\mathrm{a}}\right)$ & 20 & $17.2(11.2-24.9)$ & 22 & $7.6(4.9-11)$ \\
\hline$\geq 80 \mathrm{~cm}$ & 173 & $98.9(96.4-99.8)$ & 96 & $82.8(75.1-88.8)$ & 269 & $92.4(89.0-95.1)$ \\
\hline BMI & 175 & $30.7(28.1-33.9)$ & 116 & $28.1(25.2-30.1)$ & 291 & $29.7(26.8 .0-32.3)$ \\
\hline$<25 \mathrm{~kg} / \mathrm{m}^{2}$ & 7 & $4.0(1.8-7.7)$ & 27 & $23.3(16.3-31.6)$ & 34 & $11.7(8.4-15.7)$ \\
\hline$\geq 25 \mathrm{~kg} / \mathrm{m}^{2}$ & 168 & $96.0(92.3-98.2)$ & 89 & $76.7(68.4-83.7)$ & 257 & $88.3(84.3-91.6)$ \\
\hline \multicolumn{7}{|l|}{ Blood pressure } \\
\hline SBP & 175 & $124(115-139)$ & 116 & $115(108-122)$ & 291 & $120(111-132)$ \\
\hline DBP & 175 & $76(68-83)$ & 116 & $70.5(66-75)$ & 291 & $74(67-80)$ \\
\hline $\mathrm{SBP}<130 / \mathrm{DBP}<85 \mathrm{~mm} \mathrm{Hg}$ & 90 & $51.4(44.1-58.8)$ & 108 & $93.1(87.4-96.7)$ & 198 & $68.0(62.5-73.2)$ \\
\hline$S B P \geq 130 / D B P \geq 85 \mathrm{~mm} \mathrm{Hg}$ & 85 & $48.6(41.2-55.9)$ & 8 & $6.9(3.3-12.6)$ & 93 & $32.0(26.8-37.5)$ \\
\hline Triglycerides & 175 & $201(166-283)$ & 116 & $123(96-149)$ & 291 & $174(126-228)$ \\
\hline$<150 \mathrm{mg} / \mathrm{dL}$ & 22 & $12.6(8.3-18.1)$ & 90 & $77.6(69.4-84.4)$ & 112 & $38.5(33.0-44.2)$ \\
\hline$\geq 150 \mathrm{mg} / \mathrm{dL}$ & 153 & $87.4(81.9-91.7)$ & 26 & $22.4(15.6-30.6)$ & 179 & $61.5(55.8-67.0)$ \\
\hline HDL-c & 175 & $42.5(37.9-48.1)$ & 116 & $50.1(40.4-55.1)$ & 291 & $44.3(38.9-51.2)$ \\
\hline$\geq 50 \mathrm{mg} / \mathrm{dL}$ & 26 & $14.9(10.2-20.7)$ & 60 & $51.7(42.7-60.7)$ & 86 & $29.6(24.5-35.0)$ \\
\hline$<50 \mathrm{mg} / \mathrm{dL}$ & 149 & $85.1(79.3-89.8)$ & 56 & $48.3(39.3-57.3)$ & 205 & $70.4(65.0-75.5)$ \\
\hline Glucose & 175 & $92(83.5-104)$ & 116 & $83(76-89.5)$ & 291 & $88.0(80.5-97.5)$ \\
\hline$<100 \mathrm{mg} / \mathrm{dL}$ & 118 & $67.4(60.2-74.0)$ & 110 & 94.8 (89.7-97.8) & 228 & $78.4(73.4-82.8)$ \\
\hline$\geq 100 \mathrm{mg} / \mathrm{dL}$ & 57 & $32.6(26.0-39.8)$ & 6 & $5.2(2.2-10.3)$ & 63 & $21.6(17.2-26.6)$ \\
\hline
\end{tabular}

${ }^{a}$ Not available

the participants in our study presented MetS, under the criteria published by Alberti et al. in 2009 [21], which represents a much higher percentage than the previously mentioned for the Mayan population [26], and it is even higher than the one reported for the overall Mexican population [27]. Our study population is conformed by a high percentage of native peoples (35\%), with low educational levels (36\%). Moreover, they live in poor household conditions with low availability of public services. They belong to population groups who in the last decades have changed their diet and physical activity, adopting habits and activities that predispose them to suffer various diseases [28], especially those of cardiovascular and endocrine-metabolic nature. As mentioned above, the study population is a vulnerable population at high risk to develop these important diseases, due to the interaction of several risk factors such as diet, physical activity, and socioeconomic level, among others.

Regarding the frequency of the variant rs 9939609 of the FTO gene, we found differences between our results with those previously reported for American, European, African [23], and Mexican populations [22, 29]. This could be due to the distinction among ethnic groups analyzed. Nevertheless, it cannot be ruled out that different sample sizes might explain such differences in the results. In the case of allele frequencies reported for the East Asian population [23], no differences were observed when compared with our results.

This FTO variant has been extensively studied because it presents a strong association with obesity markers, i.e., a 3-kg increase of additional body weight for each copy of the risk allele in carriers has been documented in several populations [7]. Additionally, several research lines have linked this SNP in FTO to variations in food consumption patterns [30, 31]. Epidemiological studies suggest a positive association between the risk genotype of FTO and high energy consumption [32,33], low satiety power [30], higher protein intake [34], and greater preference for high-fat meals [35]. Although further evidence shows contradictory results, for instance, some studies have found less robust associations and outcomes in opposite directions [36-38]. A study among the German population found that SNPs of the FTO were strongly associated with obesity and T2D $[9,39]$. Other studies have also demonstrated that the carriers of the A allele were more likely to develop hyperglycemia than their counterparts with the $\mathrm{T}$ allele [40-42].

Studies carried out in other regions of Mexico have analyzed the association of FTO polymorphisms with MetS components [17, 43-45]. However, none of them has found a significant association of this polymorphism with hyperglycemia. In our study, we found a statistically significant association between the rs9939609/ 
Table 3 Comorbidities and frequency of food intake by metabolic syndrome in women from Chiapas, México

\begin{tabular}{|c|c|c|c|c|c|c|}
\hline Variables & With MetS (n) & $\%(95 \% \mathrm{Cl})$ & $\begin{array}{l}\text { Without } \\
\text { MetS }(n)\end{array}$ & $\%(95 \% \mathrm{Cl})$ & Total & $\%(95 \% \mathrm{Cl})$ \\
\hline $\mathrm{T} 2 \mathrm{D}$ & 18 & $10.3(6.4-15.4)$ & 3 & $2.6\left(^{a}\right)$ & 21 & $7.2(4.7-10.6)$ \\
\hline Hypertension & 85 & $48.6(41.2-55.9)$ & 8 & $6.9(3.3-12.6)$ & 93 & $32(26.8-37.5)$ \\
\hline Polycystic ovary syndrome & 20 & $11.4(7.4-16.8)$ & 11 & $9.5(5.1-15.8)$ & 31 & $10.7 \%(7.5-14.6)$ \\
\hline Smoking & 2 & $1.1\left(^{\mathrm{a}}\right)$ & 2 & $1.7\left(^{\mathrm{a}}\right)$ & 4 & $1.4\left(^{\mathrm{a}}\right)$ \\
\hline Alcoholic beverage consumption & 52 & $29.7(23.3-36.8)$ & 43 & $31.7(28.7-46.1)$ & 95 & $32.6(27.5-38.2)$ \\
\hline \multicolumn{7}{|l|}{ Frequency of food group intake } \\
\hline \multicolumn{7}{|l|}{ Dairy products } \\
\hline 0-1 times per week & 51 & $29.5(23.1-36.6)$ & 31 & $27.2(19.7-35.9)$ & 82 & $28.6(23.6-34.0)$ \\
\hline 2-4 times per week & 51 & $29.5(23.1-36.6)$ & 45 & $39.5(30.9-48.6)$ & 96 & $33.4(28.2-39.1)$ \\
\hline$\geq 5$ times per week & 71 & $41.0(33.9-48.5)$ & 38 & $33.3(25.2-42.3)$ & 109 & $38.0(32.5-43.7)$ \\
\hline \multicolumn{7}{|l|}{ Fruits } \\
\hline 0-1 times per week & 36 & $20.8(15.3-27.3)$ & 26 & $22.8(15.8-31.1)$ & 62 & $21.6(17.1-26.6)$ \\
\hline 2-4 times per week & 68 & $39.3(32.3-46.7)$ & 32 & $28.1(20.4-36.8)$ & 100 & $34.8(29.5-40.5)$ \\
\hline$\geq 5$ times per week & 69 & $39.9(32.8-47.3)$ & 56 & $49.1(40.1-58.2)$ & 125 & $43.6(37.9-49.3)$ \\
\hline \multicolumn{7}{|l|}{ Vegetables } \\
\hline 0-1 times per week & 27 & $15.6(10.8-21.6)$ & 21 & $18.4(12.1-26.3)$ & 48 & $16.7(12.8-21.4)$ \\
\hline 2-4 times per week & 82 & $47.4(40.1-54.8)$ & 52 & $45.6(36.7-54.8)$ & 134 & $46.7(41.0-52.5)$ \\
\hline$\geq 5$ times per week & 64 & $37.0(30.1-44.4)$ & 41 & $36.0(27.6-45.0)$ & 105 & $36.6(31.2-42.3)$ \\
\hline \multicolumn{7}{|l|}{ Red meats } \\
\hline $0-1$ times per week & 106 & $61.3(53.9-68.3)$ & 65 & $57.0(47.8-65.8)$ & 171 & $59.6(53.8-65.1)$ \\
\hline 2-4 times per week & 61 & $35.3(28.4-42.6)$ & 42 & $36.8(28.4-45.9)$ & 103 & $35.9(30.5-41.6)$ \\
\hline$\geq 5$ times per week & 6 & $3.5(1.5-7.0)$ & 7 & $6.1(2.8-11.7)$ & 13 & $4.5(2.6-7.4)$ \\
\hline \multicolumn{7}{|l|}{ Poultry } \\
\hline 0-1 times per week & 94 & $54.3(46.9-61.6)$ & 60 & $52.6(43.5-61.6)$ & 154 & $53.7(47.9-59.4)$ \\
\hline 2-4 times per week & 76 & $43.9(36.7-51.4)$ & 48 & $42.1(33.3-51.3)$ & 124 & $43.2(37.6-49.0)$ \\
\hline$\geq 5$ times per week & 3 & $1.7\left(^{(a)}\right.$ & 6 & $5.3(2.2-10.5)$ & 9 & $3.1(1.6-5.6)$ \\
\hline \multicolumn{7}{|l|}{ Fish and shellfish } \\
\hline 0-1 times per week & 153 & $88.4(83.0-92.6)$ & 104 & $91.2(85.0-95.4)$ & 257 & $89.5(85.6-92.7)$ \\
\hline 2-4 times per week & 20 & $11.6(7.4-17.0)$ & 9 & $7.9(4.0-13.9)$ & 29 & $10.1(7.0-14.0)$ \\
\hline$\geq 5$ times per week & 0 & $0\left(^{(a)}\right.$ & 1 & $0.9\left(^{a}\right)$ & 1 & $0.3\left({ }^{\mathrm{a}}\right)$ \\
\hline \multicolumn{7}{|l|}{ Cereals and tubers ${ }^{\mathrm{a}}$} \\
\hline 0-1 times per week & 0 & $0\left(^{(a)}\right.$ & 1 & $0.9^{(\mathrm{a})}$ & 1 & $0.3\left({ }^{(a)}\right.$ \\
\hline$\geq 5$ times per week & 173 & 100 & 113 & $99.1(96.0-99.9)$ & 286 & $99.7(98.4-100.0)$ \\
\hline \multicolumn{7}{|l|}{ Legumes } \\
\hline 0-1 times per week & 8 & $4.6(2.2-8.5)$ & 10 & $8.8(4.6-15.0)$ & 18 & $6.3(3.9-9.5)$ \\
\hline 2-4 times per week & 35 & $20.2(14.8-26.7)$ & 31 & $27.2(19.7-35.9)$ & 66 & $23.0(18.4-28.1)$ \\
\hline$\geq 5$ times per week & 130 & $75.1(68.3-81.1)$ & 73 & $64.0(55.0-72.4)$ & 203 & $70.7(65.3-75.8)$ \\
\hline \multicolumn{7}{|l|}{ Sugar-sweetened beverages } \\
\hline 0-1 times per week & 95 & $54.9(47.5-62.2)$ & 64 & $56.1(47.0-65.0)$ & 159 & $55.4(49.6-61.1)$ \\
\hline 2-4 times per week & 55 & $31.8(25.2-39.0)$ & 36 & $31.6(23.6-40.5)$ & 91 & $31.7(26.5-37.3)$ \\
\hline$\geq 5$ times per week & 23 & $13.3(8.9-18.9)$ & 14 & $12.3(7.2-19.2)$ & 37 & $12.9(9.4-17.1)$ \\
\hline
\end{tabular}

${ }^{\mathrm{a}}$ Not available

FTO and hyperglycemia. Women with TA/AA genotypes showed a higher probability of hyperglycemia than women with the TT genotype $(p=0.007)$.

Differences between our results and those reported in the literature may be due to different factors, for example, the ethnicity of the population evaluated, differences in body composition, diet, and the presence of other comorbidities [30].

It is remarkable that no previous studies have been carried out in this Mayan region of Mexico on the 
Table 4 Comparison of the allele frequencies of rs-9939609/FTO between our study population with other population studies

\begin{tabular}{|c|c|c|c|c|c|c|c|}
\hline \multirow[t]{2}{*}{ Gene/SNP } & \multirow[b]{2}{*}{ Allele } & \multirow{2}{*}{$\begin{array}{l}\text { Allele frequency in our study } \\
\text { Women from Chiapas, Mexico }\end{array}$} & \multicolumn{5}{|c|}{ Reference Allele Frequency (gnomAD [22] and The Page Study [23]) } \\
\hline & & & $\begin{array}{l}\text { American } \\
\text { population }^{\mathrm{a}}\end{array}$ & $\begin{array}{l}\text { European } \\
\text { population }^{a}\end{array}$ & $\begin{array}{l}\text { East Asian } \\
\text { population }^{\mathrm{a}}\end{array}$ & $\begin{array}{l}\text { African } \\
\text { population }\end{array}$ & $\begin{array}{l}\text { Mexican } \\
\text { population }^{b}\end{array}$ \\
\hline \multirow[t]{4}{*}{ FTO/RS9939609 } & $\mathrm{T}$ & 0.8935 & 0.6820 & 0.5924 & 0.8621 & 0.5217 & 0.7442 \\
\hline & $p$-value* & & $<0.001$ & $<0.001$ & 0.1341 & $<0.001$ & $<0.001$ \\
\hline & A & 0.1065 & 0.3179 & 0.4075 & 0.1379 & 0.4782 & 0.2558 \\
\hline & $p$-value* & & $<0.001$ & $<0.001$ & 0.1341 & $<0.001$ & $<0.001$ \\
\hline
\end{tabular}

${ }^{*}$ Two-sample tests on the equality of proportions

${ }^{\text {a }}$ Data obtained from gnomAD

${ }^{b}$ Data obtained from The Page Study

Table 5 Associations between rs9939609-FTO and hyperglycemia in women from Mayan communities of Chiapas, Mexico

\begin{tabular}{|c|c|c|c|c|c|}
\hline \multirow{2}{*}{$\begin{array}{l}\text { SNP/gene } \\
\text { rs9939609-FTO }\end{array}$} & \multicolumn{3}{|c|}{ Genotypes $n$ (\%) } & \multicolumn{2}{|c|}{ Dominant model $^{a}$} \\
\hline & TT & TA & AA & OR $(95 \% \mathrm{Cl})$ & $p$-value \\
\hline $\begin{array}{l}\text { Normal glycemia } \\
\quad \text { (serum glu- } \\
\text { cose }<100 \mathrm{mg} / \\
\mathrm{dL} \text { ) }\end{array}$ & $189(64.9)$ & $35(12.0)$ & $4(1.4)$ & $2.6(1.3-5.3)$ & 0.007 \\
\hline $\begin{array}{l}\text { Hyperglycemia } \\
\text { (serum glu- } \\
\text { cose } \geq 100 \mathrm{mg} / \\
\mathrm{dL} \text { ) }\end{array}$ & $44(15.1)$ & $19(6.5)$ & $0(0)$ & & \\
\hline
\end{tabular}

a The model was adjusted for age (years, continuous), BMI ( $\mathrm{kg} / \mathrm{m}^{2}$, continuous), schooling (years, continuous), and presence of T2D

relationship of this rs9939609-FTO variant with MetS components. This paper would be the first one to report for Mayan indigenous populations an association between the presence of A allele of rs9939609/FTO and hyperglycemia.

\section{Conclusions}

In our study, the TA/AA genotypes of the rs9939609FTO polymorphism increased the risk of hyperglycemia among women from three Mayan regions of Chiapas, Mexico. This finding has never been reported before in the Mayan indigenous population from Chiapas, specifically, in women with a high prevalence of MetS (60\%).

Thus, this investigation sets up the basis to understand the influence of a common variant on cardiometabolic risk factors among this population.

However, further studies in the Mexican indigenous population are required, particularly in the most vulnerable groups to generate more evidence about this topic.
Finally, on the basis of our results, we recommend to implement effective public health policies to control and prevent the increasing MetS prevalence and its cardiovascular effects among the indigenous population of Mexico.

\begin{abstract}
Abbreviations
MetS: Metabolic syndrome; SNPs: Single nucleotide polymorphisms; FTO: Fat mass and obesity-associated gene; IR: Insulin resistance; T2D: Type 2 diabetes; HBP: High blood pressure; BMI: Body mass index; OB: Obesity; HDL-c: Highdensity lipoprotein cholesterol; SBP: Systolic blood pressure; DBP: Diastolic blood pressure; HWE: Hardy-Weinberg equilibrium; OR: Odds ratio; Cl: Confidence intervals; CVD: Cardiovascular disease; WHO: World Health Organization; NCEP-ATPIII: National Cholesterol Education Program Adult Treatment Panel III.
\end{abstract}

\section{Acknowledgements}

We thank the study participants for their collaboration and to all the personne who assisted in the fieldwork, specially to the group of dietitians from Universidad de Ciencias y Artes de Chiapas, Universidad del Sureste, and Instituto de Estudios Superiores de Chiapas; the Biochemistry Unit of the National Medical Center of the 21st Century, in Mexico City, particularly to Dr. Miguel CruzLópez for his invaluable contribution to the genotyping analysis.

\section{Authors' contributions}

H.O.-D-L conceived and directed the project. H.O.-D-L and P.E.N.-O. designed and planned the study. E.F-G and P.E.N.-O. supervised the data collection. P.E.N.-O, A.V.-S., and D.L-M conducted the analysis of genotyping at the Biochemistry Unit, Specialties Hospital, National Medical Center, Century XXI IMSS. R.S.-H. and P.E.N.-O performed the statistical analysis. H.O.-D-L, P.E.N.-O, I.C.-Q., and C.A.I.-N. contributed to the analysis and interpretation of the results. P.E.N.-O. and H.O.-D-L wrote the manuscript with contributions from all co-authors. All the co-authors revised the manuscript and approved the final version.

\section{Funding}

This study was supported by the National Council for Science and Technology of Mexico (CONACYT). PNO received a PhD scholarship from CONACYT. IC-Q received a postdoctoral scholarship from CONACYT.

\section{Availability of data and materials}

The datasets used and/or analyzed during the current study are available from the corresponding author on reasonable request.

\section{Declarations}

Ethics approval and consent to participate

The study was conducted according to the guidelines of the Declaration of Helsinki and approved by the Research Ethics Committee of El Colegio de la 
Frontera Sur (CEI-O-076/16). Informed consent was obtained from all subjects involved in the study.

\section{Consent for publication}

Not applicable.

\section{Competing interests}

The authors declare that they have no competing interests.

\section{Author details}

${ }^{1}$ Health Department, El Colegio de La Frontera Sur, San Cristóbal de Las Casas, Chiapas, Mexico. ${ }^{2}$ National Council for Science and Technology, Postgraduate College Campus Puebla, Puebla, Mexico. ${ }^{3}$ Facultad de Medicina, Universidad de Colima, Colima, Mexico. ${ }^{4}$ Instituto Estatal de Cancer, Secretaria de Salud de Colima, Colima, Mexico. ${ }^{5}$ Health Department, El Colegio de La Frontera Sur, Villahermosa, Tabasco, Mexico. ${ }^{6}$ Faculty of Nutrition and Food Science, University of Science and Arts of Chiapas, Tuxtla Gutiérrez, Chiapas, Mexico. ${ }^{7}$ School of Languages-Campus San Cristobal, Autonomous University of Chiapas, San Cristóbal de Las Casas, Chiapas, Mexico. ${ }^{8}$ Unidad de Investigación Médica en Bioquímica, Hospital de Especialidades, Centro Médico Nacional Siglo XXI. Instituto Mexicano del Seguro Social, Mexico City, Mexico.

Received: 10 February 2021 Accepted: 1 August 2021

Published online: 28 August 2021

\section{References}

1. Córdova-Villalobos J, Meléndez J, Lara-Esqueda A, et al. Chronic noncommunicable diseases in Mexico: epidemiologic synopsis and integral prevention. Salud Pública Méx. 2008:50:419-27.

2. De Fronzo R, Ferrannini E. Insulin resistance: a multifocal syndrome responsible for NIDDM, obesity, hypertension, dyslipidemia and atherosclerotic cardiovascular disease. Diabetes Care. 1991;14:173-94.

3. Stern M. The insulin resistance syndrome: the controversy is dead, long live the controversy. Diabetologia. 1994;37:956-8. https://doi.org/10. 1007/BF00400955.

4. Isomma B, Almgren P, Tuomi T, et al. Cardiovascular morbidity and mortality associated with the metabolic syndrome. Diabetes Care. 2001;24:6839. https://doi.org/10.2337/diacare.24.4.683.

5. Groop L. Genetics of the metabolic syndrome. Br J Nutr. 2000;83:39-48. https://doi.org/10.1017/s0007114500000945.

6. Beck-Nielsen H, Groop L. Metabolic and genetic characterization of prediabetic states. Sequence of events leading to non-insulin dependent diabetes mellitus. J Clin Invest. 1994;94:1714-21. https://doi.org/10.1172/ JCl117518.

7. Frayling T, Timpson N, Weedon M, et al. A common variant in the FTO gene is associated with body mass index and predisposes to childhood and adult obesity. Science. 2007;316:889-94. https://doi.org/10.1126/ science.1141634.

8. Dina C, Meyre D, Gallina S, et al. Variation in FTO contributes to childhood obesity and severe adult obesity. Nat Genet. 2007;39:724-6. https://doi. org/10.1038/ng2048.

9. Scuteri A, Sanna S, Chen W, et al. Genome-wide association scan shows genetic variants in the FTO gene are associated with obesity-related traits. PLoS Genet. 2007;3:1200-10. https://doi.org/10.1371/journal. pgen.0030115.

10. Chang Y, Liu P, Lee W, et al. Common variation in the fat mass and obesity-associated (FTO) gene confers risk of obesity and modulates BMI in the Chinese population. Diabetes. 2008;57:2245-52. https://doi. org/10.2337/db08-0377.

11. Fang H, Li Y, Du S, et al. Variant rs9939609 in the FTO gene is associated with body mass index among Chinese children. BMC Med Genet. 2010;11:136. https://doi.org/10.1186/1471-2350-11-136.

12. Grant S, Li M, Bradfield J, et al. Association analysis of the FTO gene with obesity in children of Caucasian and African ancestry reveals a common tagging SNP. PLoS One. 2008;3:1746. https://doi.org/10.1371/ journal.pone.0001746.
13. Song Y, You N, Hsu Y, et al. FTO polymorphisms are associated with obesity but not diabetes risk in postmenopausal women. Obesity. 2008;16:2472-80. https://doi.org/10.1038/oby.2008.408.

14. Villalobos M, Flores M, Villarreal M, et al. The FTO gene is associated with adulthood obesity in the Mexican population. Obesity. 2008;16:2296-301. https://doi.org/10.1038/oby.2008.367.

15. León P, Villamil H, Villalobos $M$, et al. Contribution of common genetic variants to obesity and obesity-related traits in Mexican children and adults. PLoS One. 2013:8:70640. https://doi.org/10.1371/journal.pone. 0070640.

16. Saber-Ayad M, Manzoor S, El Serafi A, Mahmoud I, Hammoudeh S, Rani A, Abusnana S, Sulaiman N. The FTO rs9939609 "A" allele is associated with impaired fasting glucose and insulin resistance in Emirati population. Gene. 2019;10(681):93-8. https://doi.org/10.1016/j.gene.2018.09. 053. Epub 2018 Sep 29. PMID: 30273662.

17. Taneera J, Prasad RB, Dhaiban S, Mohammed AK, Haataja L, Arvan P, et al. Silencing of the FTO gene inhibits insulin secretion: an in vitro study using GRINCH cells. Mol Cell Endocrinol. 2018. https://doi.org/10.1016/j. mce.2018.06.003.

18. Shimaoka I, Kamide K, Ohishi M, Katsuya T, Akasaka H, Saitoh S, et al. Association of gene polymorphism of the fat-mass and obesityassociated gene with insulin resistance in Japanese. Hypertens Res. 2010;33(3):214-8

19. Flores E, Ochoa-Díaz-López H, Castro-Quezada I, et al. Intrauterine growth restriction and overweight, obesity, and stunting in adolescents of indigenous communities of Chiapas, Mexico. Eur J Clin Nutr. 2020;74:149-57. https://doi.org/10.1038/s41430-019-0440-y.

20. Causa R, Ochoa-Díaz-López H, Dor A, Rodríguez F, Solís R, Pacheco A. Emerging arboviruses (dengue, chikungunya, and Zika) in Southeastern Mexico: influence of socio-environmental determinants on knowledge and practices. Cad Saúde Pública. 2020;36:e01 10519. https://doi.org/10. 1590/0102-311×00110519.

21. Alberti KG, Eckel RH, Grundy SM, et al. Harmonizing the metabolic syndrome: a joint interim statement of the International Diabetes Federation Task Force on Epidemiology and Prevention; National Heart, Lung, and Blood Institute; American Heart Association; World Heart Federation; International Atherosclerosis Society; and International Association for the Study of Obesity. Circulation. 2009;120(16):1640-5. https://doi.org/10. 1161/CIRCULATIONAHA.109.192644.

22. The Population Architecture using Genomics and Epidemiology (PAGE) study. https://www.pagestudy.org. Accessed 10 Mar 2020.

23. Karczewski KJ, Francioli LC, Tiao G, et al. The mutational constraint spectrum quantified from variation in 141,456 humans. Nature. 2020;581:43443. https://doi.org/10.1038/s41586-020-2308-7.

24. Aguilar C, Rojas R, Gómez F, et al. High prevalence of metabolic syndrome in Mexico. Arch Med Res. 2004;35:76-81. https://doi.org/10.1016/j. arcmed.2003.06.006.

25. Lorenzo C, Williams K, González C, Haffner S. The prevalence of the metabolic syndrome did not increase in Mexico City between 1990-1992 and 1997-1999 despite more central obesity. Diabetes Care. 2005;28:2480-5. https://doi.org/10.2337/diacare.28.10.2480.

26. Castro C, Hernández V, Arjona R. Prevalencia de Síndrome Metabólico en sujetos adultos que viven en Mérida, Yucatán, Mexico. Rev Bioméd. 2001;22:49-58. https://doi.org/10.32776/revbiomed.v22i2.100.

27. Gutiérrez A, Datta S, Méndez R. Prevalence of metabolic syndrome in Mexico: a systematic review and meta-analysis. Metab Syndr Relat Disord. 2018;16:395-405. https://doi.org/10.1089/met.2017.0157.

28. RuizW, Gurri FD. La doble carga de la transición nutricional en zonas rurales de la frontera sur. In: Ochoa H, Academia Nacional de Medicina de México, editors. La Frontera sur de México, ¿Una salud en crisis?. CDMX: Academia Nacional de Medicina de México; 2018. p. 39-48.

29. Cruz M, Valladares A, Garcia J, et al. Candidate gene association study conditioning on individual ancestry in patients with type 2 diabetes and metabolic syndrome from Mexico City. Diabetes Metab Res Rev. 2010;26:261-70. https://doi.org/10.1002/dmrr.1082.

30. Wardle J, Carnell S, Haworth C, Faroogi I, O'Rahilly S, Plomin R. Obesity associated genetic variation in FTO is associated with diminished satiety. J Clin Endocrinol Metab. 2008;3:3640-3. https://doi.org/10.1210/jc. 2008-0472. 
31. Tanofsky M, Han J, Anandalingam K, et al. The FTO gene rs9939609 obesity-risk allele and loss of control over eating. Am J Clin Nutr. 2009;90:1483-14888. https://doi.org/10.3945/ajen.2009.28439.

32. Cecil J, Tavendale R, Watt P, Hetherington M, Palmer C. An obesity-associated FTO gene variant and increased energy intake in children. N Engl J Med. 2008;359:2558-66. https://doi.org/10.1056/NEJMoa0803839.

33. Qi Q, Downer M, Kilpelainen T, et al. Dietary intake, FTO genetic variants, and adiposity: a combined analysis of over 16,000 children and adolescents. Diabetes. 2015:64:2467-76. https://doi.org/10.2337/db14-1629.

34. Tanaka T, Ngwa J, van-Rooij FJA, et al. Genome-wide meta-analysis of observational studies shows common genetic variants associated with macronutrient intake. Am J Clin Nutr. 2013;97:1395-402. https://doi.org/ 10.3945/ajen.112.052183.

35. Timpson N, Emmett P, Frayling T, et al. The fat mass- and obesity-associated locus and dietary intake in children. Am J Clin Nutr. 2008;88:971-8. https://doi.org/10.1093/ajcn/88.4.971.

36. Livingstone K, Celis C, Lara J, et al. Associations between FTO genotype and total energy and macronutrient. Obes Rev. 2015;16:666-78. https:// doi.org/10.1111/obr.12290.

37. Steemburgo T, Azevedo M, Gross J, Milagro F, Campion J, Martínez J. The rs9939609 polymorphism in the FTO gene is associated with fat and fiber intakes in patients with type 2 diabetes. J Nutrigenet Nutrigenomics. 2013;6:97-106. https://doi.org/10.1159/000350741.

38. Speakman J, Rance K, Johnstone A. Polymorphisms of the FTO gene are associated with variation in energy intake, but not energy expenditure. Obesity. 2008;16:1961-5. https://doi.org/10.1038/oby.2008.318.

39. Hinney A, Nguyen TT, Scherag A, et al. Genome wide association (GWA) study for early onset extreme obesity supports the role of fat mass and obesity associated gene (FTO) variants. PLoS One. 2007;2:e1361. https:// doi.org/10.1371/journal.pone.0001361.

40. Sikhayeva N, Iskakova A, Saigi-Morgui N, Zholdybaeva E, Eap CB, Ramanculov E. Association between 28 single nucleotide polymorphisms and type 2 diabetes mellitus in the Kazakh population: a case-control study. BMC Med Genet. 2017;18:76. https://doi.org/10.1186/s12881-017-0443-2.

41. Lappalainen T, Kolehmainen M, Schwab U, et al. Association of the FTO gene variant (rs9939609) with cardiovascular disease in men with abnormal glucose metabolism - the Finnish Diabetes Prevention Study. Nutr Metab Cardiovasc Dis. 2011;21:691-8. https://doi.org/10.1016/j.numecd. 2010.01.006.

42. Szkup M, Owczarek AJ, Schneider D, Brodowski J, Łój B, Grochans E. Associations between the components of metabolic syndrome and the polymorphisms in the peroxisome proliferator-activated receptor gamma (PPAR- $\gamma$ ), the fat mass and obesity-associated (FTO), and the mela-nocortin-4 receptor (MC4R) genes. Aging. 2018;10:72-82. https://doi.org/10. 18632/aging.101360.

43. López G, Estrada A, Suárez T, Tejero M, Fernández J, Galván M. Common polymorphisms in MC4R and FTO genes are associated with BMI and metabolic indicators in Mexican children: differences by sex and genetic ancestry. Gene. 2020;754:144840. https://doi.org/10.1016/j.gene.2020. 144840.

44. Saucedo R, Valencia J, Gutierrez C, et al. Gene variants in the FTO gene are associated with adiponectin and TNF-alpha levels in gestational diabetes mellitus. Diabetol Metab Syndr. 2017;9:32. https://doi.org/10.1186/ s13098-017-0234-0.

45. Jiménez A, Musalem C, Cárdenas H, et al. Common polymorphisms linked to obesity and cardiovascular disease in Europeans and Asians are associated with type 2 diabetes in Mexican Mestizos. Medicina (Kaunas). 2019;55:40. https://doi.org/10.3390/medicina55020040.

\section{Publisher's Note}

Springer Nature remains neutral with regard to jurisdictional claims in published maps and institutional affiliations.
Ready to submit your research? Choose BMC and benefit from:

- fast, convenient online submission

- thorough peer review by experienced researchers in your field

- rapid publication on acceptance

- support for research data, including large and complex data types

- gold Open Access which fosters wider collaboration and increased citations

- maximum visibility for your research: over $100 \mathrm{M}$ website views per year

At BMC, research is always in progress.

Learn more biomedcentral.com/submissions 